\title{
İntradiyalitik Besin Alımı ve İntradiyalitik Hipotansiyon
}

\author{
Intradialytic Food Intake and Intradialytic Hypotension
}

Melek AVCI' ${ }^{1}$, Fatma ARIKAN ${ }^{2}$

${ }^{I}$ Öğretim Görevlisi-Akdeniz Üniversitesi, Sağlık Hizmetleri Meslek Yüksek Okulu, Tıbbi Hizmetler ve Teknikler Bölümü Diyaliz Programı, Antalya, Türkiye

${ }^{2}$ Dr. Öğr. Üyesi-Akdeniz Üniversitesi, Hemşirelik Fakültesi, İç Hastalıkları Hemşireliği AD, Antalya, Türkiye

Geliş Tarihi / Received :

03 Eylül 2020

Kabul Tarihi / Accepted:

26 Eylül 2020

\section{İletişim yazarı \\ Correspondence author \\ Melek AVCI}

E-posta: mlkavc07@gmail.com

\section{ORCID:}

Melek AVCI

https://orcid.org/0000-0003-0607-7298

Fatma ARIKAN

https://orcid.org/0000-0003-0481-1903

\section{Özet}

İntradiyalitik hipotansiyon diyaliz sırasında en sık karşılaşılan komplikasyonlardan biridir. Hemodiyaliz hastaları için büyük bir problem olan intradiyalitik hipotansiyonun, diyaliz sırasında besin alımı ile ilişkili olduğu ifade edilmekle birlikte hipoglisemi, malnütrisyon, ek besin sağlama gibi nedenlerden dolayı intradiyalitik beslenmenin ülkemizde ve dünyada desteklendiği bilinmektedir. Diyaliz sırasında hastaların yemek yemesine izin verilmesi hala tartışmalıdır ve diyaliz merkezlerinde intradiyalitik beslenme konusunda çeşitli uygulamalar mevcuttur. Bu derlemede intradiyalitik hipotansiyon, intradiyalitik hipotansiyonun beslenme ile ilişkisi, önleme, tedavi ve hemşirelik yaklaşımları konusunda bilgilere yer verilmiştir.

Anahtar Kelimeler: Hemşirelik; Hemodiyaliz; Kan basınc1; İntradiyalitik besin alımı; İntradiyalitik hipotansiyon.

\begin{abstract}
Intradialytic hypotension is one of the most common complications encountered during dialysis. It is stated that intradialytic hypotension, which is a major problem for hemodialysis patients, is associated with food intake during dialysis, and it is known that intradialytic nutrition is supported in our country and the world due to reasons such as hypoglycemia, malnutrition, and supplying nutrients. Allowing patients to eat during dialysis is still controversial, and there are various practices regarding intradialytic feeding in dialysis centers. In this review, information about intradialytic hypotension, the relationship of intradialytic hypotension with nutrition, prevention, treatment, and nursing approaches are included.
\end{abstract}

Key Words: Nursing; Hemodialysis; Blood pressure; Intradialytic food intake; Intradialytic hypotension. 


\section{GİRIS}

Kronik böbrek hastalığ $(\mathrm{KBH})$ sık görülen, morbidite ve mortalitesi yüksek olan, yaşam kalitesini düşüren ve erken tanı ve fark edilme oranı çok az, ekonomik yükü ise fazla olan bir hastalıktır (1) Türk Nefroloji Derneği (TND) tarafindan yapılan Türkiye Kronik Böbrek Hastalığg Prevalans Çalışmasına (CREDIT) göre ülkemizde görülme oranı kadınlarda (\%55.7) daha fazla olmakla birlikte \%15.7'dir (2). TND ve Sağl1k Bakanlığı'nın yayınladığı ortak rapora göre 2017 y1lında ülkemizde kronik hemodiyaliz (HD) / periton diyalizi (PD) programinda ya da fonksiyonel greft ile takip edilen 77.311 hasta bulunmaktadir. $\mathrm{Bu}$ hastalardan 58.635'inin $\mathrm{HD}$, 3.346`sının PD programına kayıtlı olduğu, bunların 10.552' sinin ise (9.676 HD, $876 \mathrm{PD})$ 2017 y1lı içerisinde renal replasman tedavilerine başladığı bilinmektedir (3).

Hemodiyaliz hastalarında diyaliz sirasinda en sik karşılaşılan komplikasyonlarından biri hipotansiyondur ve HD hastaları için mortalitenin en önemli sebeplerinden biridir (4-7). Hipotansiyonun diyaliz sırasında beslenme ile ilișkili olduğu ifade edilmektedir $(4,8)$. İntradiyalitik beslenmenin arteriyel kan basincinda düşüşe ve hemodinamik bozukluklara neden olduğu bildirilmiştir. $\mathrm{Bu}$ sebeplerle HD hastalarının diyaliz esnasında besin tüketmeleri önerilmezken, $(4,8-17)$ HD tedavisin katabolik doğası nedeniyle oluşan protein enerji malnütrisyonunu düzeltmek, hipoalbuminemiyi düzeltmek, yaşam kalitesini artırmak, ek besin sağlamak gibi sebeplerle de hastaların intradiyalitik besin tüketimi önerilmektedir (18, 19).

Yayınlanmış veriler, intradiyalitik besin tüketiminin genel olarak yararlı olup olmadığı konusunda belirsizlik yaratmaktadır. Hastaların HD sırasında besin tüketimine izin verilmesi durumunun tartışmalı olması nedeniyle HD merkezlerinde intradiyalitik beslenme konusunda farklı uygulamalar mevcuttur $(18,19)$.

\section{İntradiyalitik Hipotansiyon}

Hemodiyaliz sırasında kan basıncinda 1lıml bir azalma olması beklenen bir durumdur ancak intradiyalitik hipotansiyon (IDH), diyaliz prosedürüne abartılı veya paradoksal bir cevap olarak ortaya ç1kan özel durumdur (20). İDH, HD seanslarının \%20 ile \%30'unda ortaya çıkan, hastaların yaşam kalitesini azaltan ve mortalite riskini artıran, renal replasman tedavisinin en s1k ve ciddi komplikasyonlarından biridir (7, 21-23). IDH'nin evrensel olarak kabul görmüş bir tanımı olmamakla birlikte, IDH; sistolik arter basıncında görülen $20 \mathrm{mmHg}$ ve daha fazla ani düşüş veya ortalama arter basincinda $10 \mathrm{mmHg}$ ve fazlas1 düşüşle birlikte esneme, iç çekme, bulantı, kusma, kas krampları, huzursuzluk, baş dönmesi, bayılma ve anksiyete gibi semptomların da eşlik ettiği bir durumdur $(9,16,23,24)$.

İntradiyalitik hipotansiyon gelişimi genellikle tedavi hedeflerine ulaşmayı engeller ve hastanın diyalizinin erken sonlandırılmasina neden olabilir. Tekrarlı IDH gelişimi diyaliz yetersizliğine ve hipervolemiye neden olabilir $(16,24)$. Hastaların genel sağlık durumunun bozulmasının yanı sira, intradiyalitik hipotansiyondan kaynaklanan ani doku hipoksisi ve hipoperfüzyon diyaliz hastalarında önemli bir morbidite nedenidir (17). Hipotansif atakları fazla olan hastalarda mortalitenin başlıca sebebi de kardiyak sorunlardır (10).

Hemodiyaliz esnasında oluşacak hipotansiyondan sorumlu etmenlerin başında diyaliz solüsyonunun sıcaklığı, asetatlı diyaliz solüsyonu kullanımı, diyaliz sırasında besin tüketimi, doku iskemisi, otonom nöropati, ultrafiltrasyon (UF) gibi etmenler gelmektedir $(4,5,16)$. Yapılan çalışmalarda UF ile IDH arasında doğru orantılı bir ilișki olduğu bulunmuştur (5). Diyaliz seansında 2 ila 4 litre arasında yapılan UF vücut kan hacminin yaklaşık olarak \%40-60 oluşturması nedeni ile hipotansiyon gelişmesi çok da şaşırtıcı bir durum değildir (25). Ayrıca diyaliz solüsyonunun $37^{\circ} \mathrm{C}$ ve daha sicak olması damarlarda vazodilatasyona neden olur ve hastada hipotansiyon gelişebilir. Hipotansiyona yatkın olduğu düşünülen hastalarda diyalizat 1sısı düşük tutularak olası hipotansiyonlardan hasta korunmuş olur (5). Hipotansiyonun en s1k görüldüğü hasta grubu yaşlılar, kardiyovasküler hastalığa sahip hastalar ve diyabeti olan hastalardır (7). 


\section{İntradiyalitik Hipotansiyon ve İntradiyalitik Beslenme İlişkisi}

Hemodiyaliz hastaları için intradiyalitik hipotansiyon büyük bir problemdir ve diyaliz sırasında besin alımı ile ilişkili olduğu bulunmuştur $(4,8)$. İntradiyalitik beslenme postprandiyal kan basınc1 yanıtını olumsuz etkileyebilir ve intradiyalitik hemodinamik instabiliteyi indükleyebilir (17). Intradiyalitik besin tüketimi splenik ve hepatik kan akımının abdominal bölgede toplanmasına neden olarak, venöz dönüşte ciddi bir azalma meydana getirmekte ve kan basıncı düşmektedir $(4,26)$.

Hemodiyaliz hastalarında bozulmuş otonom kontrol sistemleri ve UF nedeniyle kompanse edecek mekanizmalar yetersiz kalmaktadır. Özellikle IDH'ye yatkın hastaların diyaliz sirasında gıda tüketiminden kaçınması önerilmektedir (4, $8-13,16,23,24,27,28)$. HD sirasinda besin tüketimi önerilmemekle birlikte ülkemizde ve dünyada hipoglisemi, malnütrisyon, ek besin sağlama gibi nedenlerden ötürü HD tedavisi sırasında hastaların besin tüketimine izin verildiğ $i$ ve desteklendiği bilinmektedir $(4,13,29)$.

Diyaliz sırasındaki hemodinamik stabiliteye ilişkin Avrupa En İyi Uygulama Kılavuzları (EBPG), özellikle İDH'ye yatkın hastalarda, olumsuz intradiyalitik olayların ortaya çıkmasını önlemek için birinci basamak yaklaşım olarak intradiyalitik gıda tüketiminden kaçınılmasını önermiştir (9). Bu görüşün tersine 2018 tarihli bir konsensüs bildirisinde Uluslararası Renal Beslenme ve Metabolizma Derneği (ISRNM), intradiyalitik besin alımı ve takviyelerin uygulanmasinın beslenme durumunu ve klinik sonuçları iyileştirmek için bir standart bakım uygulaması olarak görülmesi gerektiği belirterek EBPG'nin görüşü ile çelişmiştir (18). Ancak HD hastalarında IDH'nin nadiren ortaya çıktığı iddia edilse de yemek yemenin bu açıdan bir risk oluşturduğu ve önlemenin, tedavi etmek için çalışmaktan daha yararlı olduğu düşünülmektedir (21).

\section{İntradiyalitik Hipotansiyonu Önleme, Tedavi ve Hemşirelik Yaklaşımları}

Hemodiyaliz öncesi hastanın diyalize hazırlanması, HD sırasında oluşabilecek komplikasyonların erken tespiti ve müdahalesi, diyalizin uygun bir şekilde sonlandırılması, hastanın kendi kendine bakımının desteklenmesi hemșirenin sorumluluğundadır. Resmî Gazetede 19 Nisan 2011 yılında yayımlanarak yürürlüğe giren ve halen yürürlükte olan Hemşirelik Kanunu'nda diyaliz hemşiresi görev yetki ve sorumluluklarının çerçevesi belirlenmiştir (30). Bu kapsamda İDH'nin belirlenmesi, önlemek için gerekli önlemlerin alınması, İDH geliştiğinde gerekli müdahalenin yapılması hemşirenin sorumluluğundadır. IDDH gelişimini önlemek için hemşire hastanın yaşam bulgularını izlemelidir ve hekim ile iş birliği yaparak gerekli müdahaleyi yapmalıdır.

Diyaliz merkezlerinde uygulanan standart HD sirasında en sik görülen İDH nedeni; plazma dolum hızını aşan UF hızının sonucudur. IDH sıklığ1 k1sa günlük HD ve uzun süreli HD ile azaltılabilir. Ne yazık ki, günlük kısa diyaliz ve uzun diyaliz seansları HD hastalarının çoğu için kolay ulaşılabilir değildir (31). Bu yüzden İDH sıklığını azaltmak için haftada üç kez rutin HD giren hastalarda UF hızını azaltmak ve interdiyalitik ağırlık kazanımı konusunda dikkatli olmak önemlidir $(5,7,31)$.

Günlük kısa diyaliz ve uzun gece diyalizi, İDH sıklığında belirgin bir azalma meydana getirmektedir. Geleneksel üç kez haftalık HD ile karşılaştırıldığında, UF oranları gece diyalizinde daha düşüktür. Dolayısı ile uzaklaştırılan sıvı daha geniş zamanda uzaklaştırılmış olacağı için daha az hipotansiyon gelişmektedir (31).

Hemodiyalizin ilk iki saatinde üre, sıvı ve solütlerdeki azalmaya bağl1 olarak plazma ozmoloritesinde bir azalma meydana gelir. Plazma ozmoloritesindeki hızlı düşüş İDH'ye eğilimi artırabilir. $\mathrm{Bu}$ etki ile mücadele etmek için yapılan sodyum profili ile plazma sodyum konsantrasyonundaki artış İDH'yi önler. Yapılan çalışmalarda aşamalı sodyum profillemenin İDH'yi azaltmada en etkili yöntem olduğu gösterilmiştir (32). Uygulanan sodyum profili ile artmış plazma sodyum oranı sonucunda artan susuzluk hissi ve dolayisı ile interdiyalitik ağırlık kazanımındaki artış gibi olumsuz etkilere neden olabileceği de unutulmamalıdır $(31,32)$. Bu yüzden düşük sodyum içerikli diyalizat ve yüksek sodyum içerikli diyalizat kullanılmamalı, diyalizat sodyum içeriği hastanın plazma sodyumundan biraz daha yüksek tutulmalıdır $(31,33)$. 
İntradiyalitik hipotansiyona yatkın olan hastada herhangi bir rahatsızlı yaratmayacak șekilde diyalizat 1sısı düşük tutulmalıdır $(5,9,26)$. Bir meta-analiz çalışmasında diyalizat 1 sısının $0.5^{\circ} \mathrm{C}$ düşürülmesinin İDH'yi önemli ölçüde azalttığ 1 gösterilmiştir (34). Genellikle diyalize $37^{\circ} \mathrm{C}$ diyalizat 1sısı ile başlanılır, ancak bu normal vücut sıcaklığının üzerindedir. Diyalizatın 1sısının hastaya özel ayarlanması daha doğrudur. Hastanın timpanik membran sıcaklığı ölçülerek bunun $0.5^{\circ} \mathrm{C}$ altına diyalizat $1 \mathrm{~s} 1 \mathrm{~S} 1$ ayarlanmalıdır. Hastanın kan basıncı düştügünde ürperme hissi olup olmama durumuna göre diyalizat 1sisı azaltılmalıdır (26). Antihipertansif ilaçlar hipotansiyona sebep olabileceğinden hastalar antihipertansif ilaçlarını HD'den hemen önce almamaları konusunda uyarılmalıdır (33).

Hastaların kuru ağırlık tespiti iyi yapılmalı, kuru ağırlığının altında UF yapılmamalıdır (7). Hipotansiyona eğilimi olmayan hastalarda plazma volümünde $\% 20^{\prime}$ lik azalma genellikle ciddi bir hipotansiyon gelişmeden tolere edilebilmektedir. IDH'yi tespit ve tedavi etmede faydalı olduğu düşünülen kan volüm monitörizasyonun İDH'nin sıklığını azaltmada etkili olduğu gösterilmiştir. Kan volüm monitörizasyonu HD sırasında sürekli olarak Hemoglobin ve hematokrit değerlerinin ölçümünü yaparak İDH'nin tespit edilmesini sağlamaktadır. Bazı çalışmalarda kan volüm monitörizasyonu cihazının kullanımının IDH'nin görülme sıklı̆̆ını azalttığg gösterilmiştir (5).

Kan akım hızının yavaşlatılması; UF kontrol sistemlerinin olmadığı ve sadece asetatlı diyaliz yapılan dönemlerde hipotansiyonun düzeltilmesinde kullanılan bir yöntemdi. Ancak günümüzde kan akım hızının azaltılması yönteminin IDH'nin düzeltilmesine herhangi bir katkısının olmadığg savunulmaktadır. Tersine tekrarlı kan akım hızının azaltılmasının diyaliz yetersizliğine neden olabileceği vurgulanmaktadır (26).

Magnezyum (Mg), damar tonüsü ve kalp ritminin düzenlenmesinde önemli bir elektrolittir. HD sırasında serum $\mathrm{Mg}$ ile hipotansiyon gelişimi arasında anlamlı negatif bir korelasyon olduğu, diyaliz öncesi serum $\mathrm{Mg}$ düzeyinin yüksekliği IDH için bir risk faktörü olduğu gösterilmiştir (35). İntradiyalitik plazma magnezyum konsantrasyonlarında düşüşle birlikte İDH'nin arttığ1 gösterilmiştir. Standart $0,5 \mathrm{mmol} / \mathrm{L}$ 'nin üzerindeki diyalizat $\mathrm{Mg}$ konsantrasyonlarının, İDH'nin azaltılmasında bir avantaj sağlayabileceği bildirilmiştir. Ancak hipermagnezemiyi önlemek için de $\mathrm{Mg}$ konsantrasyonlarının izlenmesi gerektiği vurgulanmıştır (32).

İntradiyalitik hipotansiyon geliştiğinde acil tedavi izotonik $\mathrm{NaCl}$ veya hipertonik ajanlar bolus tarzında başlanarak hastaya trendelenburg pozisyonu verilmeli (solunum sikıntısı yoksa) ve UF hızı yavaşlatılmalı hatta gerekirse sıfırlanmalıdır. Bolus tarzında albumin verilmesi daha etkili bir yöntem olmasına karşın pahalı bir yöntem olduğu için tercih edilmemektedir $(5,26)$.

\section{SONUÇ}

İntradiyalitik hipotansiyon diyaliz hastaları için ciddi bir problemdir ve tekrarlı IDH atakları sık hastaneye yatışlara ve kardiyovasküler problemlere sebep olabilmektedir. Hipoglisemi, malnütrisyon, ek besin sağlama gibi öncül sebeplerle hastaların diyaliz sırasında beslenmesinin desteklendiği bilinmektedir. Sağlik profesyonelleri tarafindan hastaların diyaliz sirasinda beslenmesi hastaya özgü değerlendirilmelidir. HD hastasının bakım ve eğitiminden sorumlu olan hemşirelere IDH yönünden hastaların değerlendirilmesi, izlenmesi, hasta kayıtlarının tutulması noktasında büyük rol düşmektedir. Hipotansif atak öyküsü olma, diyabetik olma ve ileri yaş gibi durumlardan ötürü İDH'ye yatkın olduğu bilinen hastaların diyaliz sırasında oluşabilecek hemodinamik bozukluklar göz önüne alındığında diyaliz sırasında tüketmesi gereken besinleri diyaliz çık1şında tüketmeleri yönünde hemşirelerin hastaları yönlendirmesi önerilir. 


\section{Kaynaklar}

1. Süleymanlar G. Kronik böbrek hastalığı. Periton Diyalizi Başvuru Kitabı. Ankara: Güneş Tıp Kitabevleri; 2019. s. 1-16.

2. Süleymanlar G, Utaş C, Arinsoy T, Ateş K, Altun B, Altiparmak MR, et al. A population-based survey of Chronic REnal Disease In Turkey - the CREDIT study. Nephrology Dialysis Transplantation. 2011;26(6):1862-71.

3. Ateş K, Süleymanlar G, Nurhan S. Türkiye'de Nefroloji, Diyaliz ve Transplantasyon-Registry 2017. TC Sağlık Bakanlığ1 ve Türk Nefroloji Derneği Ortak Raporu. 2019.

4. Kinnel K. Should patients eat during hemodialysis treatments? Nephrology Nursing Journal. 2005;32(5):513.

5. Ahsen A. Hemodiyalizin akut komplikasyonları. Kocatepe Tip Dergisi. 2011;12(1):54-60.

6. Bansal S, Ansons A, Vishwanath M. Hypotension-induced blindness in haemodialysis patients. Clinical Kidney Journal. 2014;7(4):387-90.

7. Tuna D, Ovayolu N, Kes D. Hemodiyaliz hastalarında sık karşılaşılan problemler ve çözüm önerileri. Nefroloji Hemşireliği Dergisi. 2018;13(1):17-25.

8. Benaroia M, Iliescu EA. Oral intake during hemodialysis: is there an association with intradialytic hypotension? Hemodialysis International. 2008;12(1):62-5.

9. Kooman J, Basci A, Pizzarelli F, Canaud B, Haage P, Fouque D, et al. EBPG guideline on haemodynamic instability. Nephrology Dialysis Transplantation. 2007;22(suppl_2):ii22-ii44.

10. Mahoney C. Should patients eat during dialysis? Nursing. 2007;37(10):57-8.

11. Bradshaw W. Intradialytic hypotension: a literature review. Renal Society of Australasia Journal. 2014;10(1):22- 9.

12. Chiu Y-F, Chen Y-C, Wu P-Y, Shih C-K, Chen H-H, Chen H-H, et al. Association between the hemodialysis eating index and risk factors of cardiovascular disease in hemodialysis patients. Journal of Renal Nutrition. 2014;24(3):163-71.

13. Kistler B, Benner D, Burgess M, Stasios M, Kalantar-Zadeh K, Wilund KR. To eat or not to eat-international experiences with eating during hemodialysis treatment. Journal of Renal Nutrition. 2014;24(6):349-52.

14. Assimon MM, Flythe JE. Intradialytic blood pressure abnormalities: the highs, the lows and all that lies between. American Journal of Nephrology. 2015;42(5):337-50.

15. Rocha A, Sousa C, Teles P, Coelho A, Xavier E. Frequency of intradialytic hypotensive episodes: old problem, new insights. Journal of the American Society of Hypertension. 2015;9(10):763-8.

16. Gul A, Miskulin D, Harford A, Zager P. Intradialytic hypotension. Current Opinion in Nephrology and Hypertension. 2016;25(6):545-50.

17. Agarwal R, Georgianos P. Feeding during dialysis-risks and uncertainties. Nephrology Dialysis Transplantation. 2018;33(6):917-22.

18. Kistler BM, Benner D, Burrowes JD, Campbell KL, Fouque D, Garibotto G, et al. Eating during hemodialysis treatment: a consensus statement from the International Society of Renal Nutrition and Metabolism. Journal of Renal Nutrition. 2018;28(1):4-12.

19. Fotiadou E, Georgianos PI, Chourdakis M, Zebekakis PE, Liakopoulos V. Eating during the hemodialysis session: A practice improving nutritional status or a risk factor for intradialytic hypotension and reduced dialysis adequacy? Nutrients. 2020;12(6):1703.

20. Van Buren PN, Inrig JK. Special situations: Intradialytic hypertension/chronic hypertension and intradialytic hypotension. Seminars in dialysis. 2017;30(6):545-52.

21. De D, Xiang Ai AT. Standardising haemodialysis care by restricting nutrition during dialysis: introducing a quality improvement initiative for renal outpatients. Contemporary Nurse. 2015;50(2-3):206-13.

22. Reeves PB, Mc Causland FR. Mechanisms, clinical implications, and treatment of intradialytic hypotension. Clinical Journal of the American Society of Nephrology. 2018;13(8):1297-303.

23. Workgroup KD. K/DOQI clinical practice guidelines for cardiovascular disease in dialysis patients. Am J Kidney Dis. 2005;45:S1-S153.

24. Flythe JE, Xue H, Lynch KE, Curhan GC, Brunelli SM. Association of mortality risk with various definitions of intradialytic hypotension. Journal of the American Society of Nephrology. 2015;26(3):724-34.

25. Soliman RA, Fawzy M, Kandil H, Abd el Fattah A. Assessment of hypotension during dialysis as a manifestation of myocardial ischemia in patients with chronic renal failure. The Egyptian Journal of Critical Care Medicine. 2014;2(1):138.

26. Sherman R, Daugisdas J, Ing TS. Hemodiyaliz sırasında sık görülen komplikasyonlar. In: Daugirdas JT, editor. Diyaliz El Kitabı. 5.Baskı. Ankara: Güneş Tıp Kitabevleri; 2020. s. 215-36. 
27. Choi MS, Kistler B, Wiese GN, Stremke ER, Wright AJ, Moorthi RN, et al. Pilot study of the effects of high-protein meals during hemodialysis on intradialytic hypotension in patients undergoing maintenance hemodialysis. Journal of Renal Nutrition. 2019;29(2):102-11.

28. Stefánsson BV, Brunelli SM, Cabrera C, Rosenbaum D, Anum E, Ramakrishnan K, et al. Intradialytic hypotension and risk of cardiovascular disease. Clinical Journal of the American Society of Nephrology. 2014;9(12):2124-32.

29. Yüksel Acar C. (2016) Kronik böbrek yetmezliği hastalarında hemodiyaliz uygulaması sırasında besin tüketme miktarının kan basıncına etkisi. Acıbadem Üniversitesi Yayımlanmamış Yüksek Lisans Tezi, İstanbul.

30. ResmiGazete. Hemşirelik Yönetmeliğinde Değişiklik Yapılmasına Dair Yönetmelik 19 Nisan 2011 [Available from: https://www.resmigazete.gov.tr/eskiler/2011/04/20110419-5.htm.

31. Davenport A. Can advances in hemodialysis machine technology prevent intradialytic hypotension? Seminars in Dialysis. 2009;22(3):231-6.

32. Vareesangthip K, Davenport A. Reducing the risk of intradialytic hypotension by altering the composition of the dialysate. Hemodialysis International. 2020;24(3):276-81.

33. Tuna S, Pakyüz SÇ, Çaydam ÖD. Sistematik Derleme: Hemodiyalizdeki Hipotansiyonun Önlenmesi. Nefroloji Hemşireliği Dergisi. 2015;10(2):63-79.

34. Eldehni MT, Odudu A, McIntyre CW. Randomized clinical trial of dialysate cooling and effects on brain white matter. Journal of the American Society of Nephrology. 2015;26(4):957-65.

35. Geng X, Yu J, Xu J, Jin S, Shao W, Wang Y, et al. Role of magnesium in the risk of intradialytic hypotension among maintenance hemodialysis patients. Hemodialysis International. 2020;24(3):351-8. 